\title{
Pregnancy outcome in patients with fibroid
}

\section{Antima Kirtikumar Maliwad, Rajal Thaker*, Parul Shah}

\begin{abstract}
Department of Obstetrics \& Gynaecology, Smt N. H. L. Municipal Medical College, Sheth V. S. General Hospital,
\end{abstract} Ahmedabad-380009, Gujarat, India

Received: 14 August 2014

Accepted: 19 August 2014

\author{
*Correspondence: \\ Dr. Rajal Thaker, \\ E-mail: rajalthaker@gmail.com
}

(C) 2014 Maliwad AK et al. This is an open-access article distributed under the terms of the Creative Commons Attribution Non-Commercial License, which permits unrestricted non-commercial use, distribution, and reproduction in any medium, provided the original work is properly cited.

\begin{abstract}
Background: Fibroids are benign smooth muscle cell tumour of the uterus. In some patients of pregnancy associated with fibroid, it does not affect the outcome of pregnancy. On the other hand, various complications have been reported. Objective of current study was to assess the prevalence and obstetric complications of fibroid during pregnancy and it management.

Methods: This was a prospective study. The study was conducted at tertiary care centre, obstertrics \& gynecology department over a period of nine months September 2013 to May 2014. Total 17 pregnant patients with $>3 \mathrm{~cm}$ fibroid were included in the study. They were followed during antenatal period. Maternal age, parity, size of fibroid, complications during pregnancy, labour, and delivery, mode of delivery and indications of cesarean section were noted.

Results: Incidence of fibroid during pregnancy was $0.4 \%$. Out of 17 patients, majority 9 (52.9\%) were between 26-30 years of age group, majority $7(41.1 \%)$ were diagnosed between 21-28 weeks and $14(82.3 \%)$ were multigravidas. Normal vaginal delivery occurred in $3(20 \%)$, while $12(80 \%)$ delivered by cesarean section. There were $8(47 \%)$ patients who had no complication whereas $9(52.9 \%)$ had some complication. Pain was present in 7 (41.1\%). PROM and preterm labour was present in $3(17.6 \%)$ and $2(11.7 \%)$ respectively. Abortion and IUD occurred in $2(11.7 \%)$ and in $1(5.8 \%)$ respectively. LBW and IUGR was present in $5(29.4 \%)$ and $3(17.6 \%)$ respectively. PPH was present in $6(35.2 \%)$. Antenatal myomectomy performed in $1(5.8 \%)$ and myomectomy at cesarean section performed in 2 $(11.7 \%)$. Blood transfusion was given to $8(47 \%)$ patients.

Conclusions: Pregnant patients who have fibroids are to be carefully screened in the antenatal period, so as to have a regular follow up. The wide spread use of ultrasonography has facilitated diagnosis and management of fibroids in pregnancy. The site and size of fibroid is very important to predict its effect on the pregnancy. In selected patients, myomectomy during antenatal period and at cesarean section can give good results and better pregnancy outcome.
\end{abstract}

Keywords: Fibroid with pregnancy, Myomectomy

\section{INTRODUCTION}

Fibroids are benign smooth muscle cell tumour of the uterus. In some patients of pregnancy associated with fibroid, it does not affect the outcome of pregnancy. On the other hand, various complications have been reported. During antepartum period, it can lead to spontaneous abortion, pain, preterm labor, premature rupture of membrane (PROM) and malpresentations. During intrapartum period it leads to dysfunctional labour and increased rate of cesarean section whereas in post-partum period, it can cause retained placenta, post-partum hemorrhage (PPH), sepsis. It can cause fetal complications like intrauterine growth restriction (IUGR), low birth weight (LBW), intra-uterine death (IUD) etc. ${ }^{1}$

\section{METHODS}

This prospective study was carried out during September 2013 to May 2014 at department of obstetrics and 
gynecology of tertiary care hospital. All pregnant patients with fibroids $>3 \mathrm{~cm}$ were included in this study. Those patients having fibroid before pregnancy and later conceived, patients having fibroid diagnosed during pregnancy and patients having fibroid diagnosed at the time of delivery were included in study. All 17 patients were followed up clinically and ultrasonically. Data of all patients was recorded as per proforma and analyzed as per age, parity, period of gestation at the time of diagnosis, mode of delivery and specific complications associated with pregnancy with fibroid.

\section{RESULTS}

During the study period, there were 4030 total deliveries. Out of these, there were 17 patients who had presented pregnancy associated with fibroid. Therefore, proportion of pregnancy with fibroid was $0.4 \%$.

Table 1: Age of patient - pregnancy with fibroid $(\mathrm{N}=17)$.

\begin{tabular}{|lll|}
\hline $\begin{array}{l}\text { Age } \\
\text { (years) }\end{array}$ & Number & Percentage \\
\hline 20 to 25 & 6 & $35.2 \%$ \\
\hline 26 to 30 & 9 & $52.9 \%$ \\
\hline 31 to 35 & 2 & $11.7 \%$ \\
\hline
\end{tabular}

As shown in Table 1, majority of patients were in age group of 26-30 years, 9 (52.9\%).

Table 2: Period of gestation at the time of diagnosis of fibroid ( $\mathrm{N}=17)$.

\begin{tabular}{|lll|}
\hline $\begin{array}{l}\text { Period of gestation } \\
\text { (weeks) }\end{array}$ & Number & Percentage \\
\hline Before pregnancy & 2 & $11.7 \%$ \\
\hline$<12$ weeks & 2 & $11.7 \%$ \\
\hline $13-20$ weeks & 2 & $11.7 \%$ \\
\hline $21-28$ weeks & 7 & $41.1 \%$ \\
\hline $29-36$ weeks & 3 & $17.6 \%$ \\
\hline At caesarean section & 1 & $5.8 \%$ \\
\hline
\end{tabular}

As shown in Table 2 majority of patients, 7 (41.1\%) were diagnosed during 21-28 weeks of gestation, whereas 2 $(11.7 \%)$ were diagnosed before pregnancy, before 12 weeks and between 13-20 weeks each.

Table 3, shows complications of pregnancy associated with fibroid. There were $8(47 \%)$ patients who had no complication whereas $9(52.9 \%)$ had some complication. Pain was present in $7(41.1 \%)$. PROM and Preterm labour was present in $3(17.6 \%)$ and $2(11.7 \%)$ respectively.

Abortion and IUD occurred in $2(11.7 \%)$ and in $1(5.8 \%)$ respectively. LBW and IUGR was present in $5(29.4 \%)$ and $3(17.6 \%)$ respectively. PPH was present in 6 $(35.2 \%)$.
Table 3: Complications - pregnancy with fibroid $(\mathrm{N}=17 *)$.

\begin{tabular}{|lll|}
\hline Complications & Number & Percentage \\
\hline No complication & 8 & $47 \%$ \\
\hline Abortion & 2 & $11.7 \%$ \\
\hline IUD & 1 & $5.8 \%$ \\
\hline Pain & 7 & $41.1 \%$ \\
\hline PROM & 3 & $17.6 \%$ \\
\hline Preterm labour & 2 & $11.7 \%$ \\
\hline LBW & 5 & $29.4 \%$ \\
\hline IUGR & 3 & $17.6 \%$ \\
\hline PPH & 6 & $35.2 \%$ \\
\hline
\end{tabular}

*More than one complication was present in some patients

Table 4: Mode of delivery - pregnancy with fibroid $(\mathrm{N}=15)$.

\begin{tabular}{|c|c|c|c|c|}
\hline \multicolumn{2}{|c|}{ Mode of delivery } & Number & Total & Percentage \\
\hline \multirow{2}{*}{$\begin{array}{l}\text { Norma } \\
\text { vaginal } \\
\text { delivery }\end{array}$} & Term & 2 & \multirow{2}{*}{3} & \multirow{2}{*}{$20 \%$} \\
\hline & Preterm & 1 & & \\
\hline \multicolumn{2}{|c|}{ Caesarean section } & 12 & 12 & $80 \%$ \\
\hline
\end{tabular}

As shown in Table 4, majority $12(80 \%)$ delivered by cesarean section.

Table 5: Myomectomy - pregnancy with fibroid.

\begin{tabular}{|lll|}
\hline $\begin{array}{l}\text { Myomectomy } \\
\text { Myomectomy in } \\
\text { antenatal period }\end{array}$ & 1 & $5.8 \%$ \\
\hline $\begin{array}{l}\text { Myomectomy at } \\
\text { caesarean section }\end{array}$ & 2 & $11.7 \%$ \\
\hline
\end{tabular}

\section{DISCUSSION}

In present study, proportion of pregnancy with fibroid was $0.4 \%$. Various studies have reported incidence of pregnancy with fibroid as $0.09 \%$ to $3.7 \%$. $^{2}$

In present study $16(94.1 \%)$ cases were diagnosed with ultrasonography and only $1(5.8 \%)$ case was diagnosed by clinical examination and confirmed by ultrasonography. Majority of fibroids 7 (41.1\%) were diagnosed between 21-28 weeks. Incidence of pregnancy with fibroid depends on population characteristics and the frequency of routine sonography. Sheiner ${ }^{3}$ and coworkers found incidence of $0.65 \%$ without ultrsonography, but with midtrimester ultrasonography Qidwai ${ }^{4}$ and coworkers found incidence of $2.7 \%$ in pregnancy with fibroid.

In our study, majority $9(52.9 \%)$, patients were in age group of 26 to 30 years. In our study, 14 (82.3\%) were multigravida and $3(17.6 \%)$ were primigravida. Hence, fibroids were less common in their first pregnancy. S. 
Kore et al. ${ }^{5}$ have reported $44 \%$ between 26 to 30 years of age group \& $77.7 \%$ were multigravida.

In our study, abortion rate was $2(11.7 \%)$. Various studies have reported abortion rate between $14-22 \% .^{5-7}$ Both patients, who aborted, had submucous fibroid and placental attachment was on the fibroid as per USG. Spontaneous miscarriage was more common with fibroid located in body, intramural and submucosal fibroids. A submucosal fibroid that projects into uterine cavity may compress the underlying endometrium and leads to endometrial dysfunction or it may distort vascular architecture that supplies and drains the endometrium at that site. If embryo chooses to implant at that site, the fibroid may interfere with normal placentation and development of definitive uteroplacental circulation and leads to spontaneous pregnancy loss. ${ }^{6}$

In our study, IUD occurred in $1(5.8 \%)$ as fetus was having congenital malformation. Matsunaga and Shiota ${ }^{8}$ have found two fold increase in the number of malformed embryos recovered from patients with uterine fibroids.

Patients who suffered from pain due to fibroid in their antepartum period were $7(41.1 \%)$. This pain is due to red degeneration of fibroid, which is actually hemorrhagic infarction. Findings include focal pain, tenderness on palpation, and sometime low grade fever and leukocytosis. Treatment consists of analgesia and observation. Most often signs and symptoms abate within few days ${ }^{9}$. Management of intractable fibroid pain that is refractory to conservative treatment includes antepartum myomectomy, and even termination of pregnancy. ${ }^{1}$ In our study 1 (5.8\%) patient underwent antepartum myomectomy due to severe pain which could not be managed conservatively. Remaining 6 (35.2\%) was managed conservatively.

In present study, Preterm labour occurred in $2(11.7 \%)$ and PROM occurred in $3(17.6 \%)$. Sheiner et al. ${ }^{3}$ and Shehla et al. ${ }^{10}$ have reported incidence of PROM $9.6 \%$ and $10 \%$ respectively. Some investigators suggested that fibroid uteri are less distensible than non-fibroid uteri, which leads to premature labor and delivery ${ }^{11}$ while other noted decreased oxytocinase activity in the gravid fibroid uterus, which may result in localized increase in oxytocin levels and predisposition to premature contractions. ${ }^{12}$

Post-partum hemorrhage (PPH) occurred in 6 (35.2\%), out of these PPH occurred in $5(29.4 \%)$ during cesarean section and $1(5.8 \%)$ after vaginal delivery. Fibroids may distort the uterine architecture and interfere with myometrial contractions leading to uterine atony and postpartum hemorrhage. ${ }^{13}$

In our study, Blood transfusion was given to $8(47 \%)$ patients. Pack Cell Volume (PCV) was given to 6 $(35.2 \%)$ of PPH patients and $1(5.8 \%)$ of those who aborted and who had myomectomy in antenatal period.
In our study, LBW were $5(29.4 \%)$ and $3(17.6 \%)$ were IUGR. Women with fibroids are at slightly increased risk of delivering a growth restricted infant ${ }^{6}$.

In our study, 3 (20\%) were vaginal delivery and $12(80 \%)$ were cesarean section. In various studies, rate of cesarean section ranges between $34 \%-73 \% .^{3,5,7,14}$ In our study, indications for cesarean sections were previous cesarean delivery, multiple fibroid and PROM. Women with fibroids were at a 3.7 fold increased risk of cesarean delievery. ${ }^{6}$ Multiple fibroids, large fibroids, fibroids in the lower uterine segment are predisposing factors for cesarean delivery. ${ }^{15}$

Resection of fibroid during pregnancy is generally contraindicated. Resection of intramural fibroid during pregnancy or at a time of delivery usually stimulates profuse bleeding. De Carolis et al. ${ }^{16}$ and Celik et al. ${ }^{17}$ have reported data on myomectomy during pregnancy where it was performed because of pain and most women had cesarean delivery. In present study, the decision to perform myomectomy was taken as a large superficial intramural fibroid of about $20 \times 20 \mathrm{~cm}$ size was associated with 18 weeks of pregnancy, making uterine size of 32 weeks gestation. The surgery was uneventful and patient delivered at full term.

Myomectomy at cesarean section can be performed in selected patients. When a low anterior wall fibroid involves lower segment, the fibroid can be removed by transverse incision across its surface and uterus opened by a corresponding incision through the posterior wall of the capsule. The reasoning behind myomectomy at cesarean section is that, uterus in the immediate postpartum period is better adapted physiologically to control haemorrhage than at any other stage of women's life. In present study, myomectomy was performed at cesarean section in $2(11.7 \%)$. Out of these $1(5.8 \%)$ fibroid was present at incision site and in $1(5.8 \%)$ it was a pedunculated fibroid.

\section{CONCLUSION}

Pregnant patients who have fibroids are to be carefully screened in the antenatal period, so as to have a regular follow up. The wide spread use of ultrasonography has facilitated diagnosis and management of fibroids in pregnancy. The site and size of fibroid is very important to predict its effect on the pregnancy. In selected patients, myomectomy during antenatal period and at cesarean section can give good results and better pregnancy outcome.

\section{ACKNOWLEDGEMENTS}

Authors would like to thank Dr. S. T. Malhan, the superintendent of Sheth V. S. general hospital, Dr. Pankaj R. Patel, the Dean of Smt N. H. L. municipal medical college for allowing to publish this paper. 
Funding: No funding sources

Conflict of interest: None declared

Ethical approval: The study was approved by the institutional ethics committee

\section{REFERENCES}

1. Ouyang DW, Economy KE, Norwitz ER. Obstetric complications of fibroids. Obstet Gynaecol Clin North Am. 2006;33:153-69.

2. Suchitra P, Sanjay R, Ranjit A. Pregnancy with fibroid. In: Suchitra P, Sanjay R, Ranjit A, eds. Fibroids. 1st ed. Mumbai: The National Book Depot; 2006: 136-146.

3. Sheiner E, Bashiri A, Levy A, Hershkovitz R, Katz M, Mazor M. Obstetrics characteristics and perinatal outcome of pregnancies with uterine leiomyomas. J Reprod Med. 2004;49:182-6.

4. Qidwai GI, Caughey AB, Jacoby AF. Obstetric outcomes in women with sonographycally identified uterine leiomyomata. Obstet Gynaecol. 2006 Feb;107(2 Pt 1):376-82.

5. Shailesh Kaur, Anantta Pandole, Aparna Hegde, Sangeeta Kulkarni, Miti Ahuja, V. R. Ambiye. Pregnancy with fibroids. J Obstet Gynaecol India. 2004;54(4):361-2.

6. Klastsky PC, Tran ND, Caughey AB, Fujimoto VY. Fibroids and reproductive outcomes: a systematic literature review from conception to delivery. Am J Obstet Gynaecol 2008;19:357-66.

7. Benson CB, Chow JS, Chang-Lee W, Hill JA 3rd, Doubilet PM. Outcome of pregnancies in women with uterine leiomyomas identified by sonography in first trimester. Clin Ultrasound. 2001;29:261-264.

8. Matsunage E, Shiota K. Ectopic pregnancy and myoma uteri. Teratogenic effect and maternal characteristics. Teratology. 1980;21:61-6.
9. F. Gary Cunningham, Kenneth J. Leveno, Steven Bloom, John C. Hauth, Dwight J. Rouse, Catherine Y. Spong. Reproductive tract abnormality. In: F. Gary Cunningham, Kenneth J. Leveno, Steven Bloom, John C. Hauth, Dwight J. Rouse, Catherine Y. Spong, eds. Williams Obstetric. 23rd ed. New York: McGraw Hill Professional; 2009: 890-911.

10. Noor S, Fawwad A, Sultana R, Bashir R, Qurat-ulain, Jalil $\mathrm{H}$, et al. Pregnancy with fibroids and its obstetrics complication. J Ayub Med Coll Abbottabad. 2009 Oct-Dec;21(4):37-40.

11. Rice JP, Kay HH, Mahony BS. The clinical significance of uterine leiomyomas in pregnancy. Am J Obstet Gynaecol. 1989;160:1212-6.

12. Blum M. Comparative study of serum CAP activity during pregnancy in malformed and normal uterus. J Perinatol Med. 1978;6:165-8.

13. Szamatowicz J, Laudanski T, Bulkszaz B, Akerlund M. Fibromyomas and uterine contractions. Acta Obstet Gynaecol Scand. 1997;76:973-6.

14. Hasan F, Arumugam K, Sivanesaratnam V. Uterine leiomyomata in pregnancy. Int $\mathbf{J}$ Gynaecol Obstet. 1991;34:45-8.

15. Vergani P, Locatelli A, Ghidini A, Andreani M, Sala F, Pezzullo JC. Large uterine leiomyomata and risk of cesarean delivery. Obstet Gynaecol. 2007 Feb;109(2 Pt 1):410-4.

16. De Carolis, Fatigante G, Ferrazzani S, Trivellini C, De Santis L, Mancuso S, et al. Uterine myomectomy in pregnant women. Fetal Diagn Ther. 2001;16:116.

17. Celik C, Acar A, Ciçek N, Gezginc K, Akyürek C. Can myomectomy be performed during pregnancy? Gynaecol Obstet Invest. 2002;53:79-83.

DOI: $10.5455 / 2320-1770 . i j \operatorname{cog} 20140984$

Cite this article as: Maliwad AK, Thaker R, Shah

P. Pregnancy outcome in patients with fibroid. Int $\mathbf{J}$ Reprod Contracept Obstet Gynecol 2014;3:742-5. 